\title{
SEIZURES AND PRAZIQUANTEL. A CASE REPORT.
}

Jaime R. TORRES R., Oscar NOYA G., Belkysyole A. de NOYA \& Alejandro MONDOLFI G.

\section{SUMMARY}

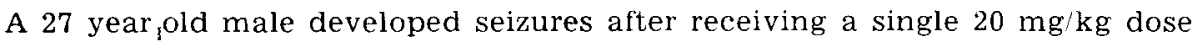
of praziquantel for the treatment of an intestinal Hymenolepis nana infection. On further clinical and laboratorial evaluations, he was found to suffer from an until then asymptomatic parenchymal brain cysticercosis. Praziquantel must be used with caution in those areas where cysticercosis represents a mayor public health problem. The occurrence of unexpected seizures in an individual being treated with the compound, must prompt clinicians to rule out cysticercosis of the CNS.

KEY WORDS: Praziquantel; Seizures; Neurocysticercosıs.

\section{INTRODUCTION}

Praziquantel ( $\mathrm{PZQ}$ ), an acylated isoquinoli ne-pirazine derivative, is a broad spectrum antitrematode drug originally developed to treat schistosomiasis, that has proved highly success ful in the treatment of diverse cestode infections.

In human intestinal cestodiasis, cure rates as high as $94 \%$ for Hymenolepis nana and $95 \%$ for Diphyllobothrium latum have been obtained after single oral doses of $25 \mathrm{mg} / \mathrm{kg}$ of $\mathrm{PZQ}$. Furthermore, $100 \%$ cure rates with the administration of $10 \mathrm{mg} / \mathrm{kg}$ of the compound are usual in Dyphyllobothrium pacificum infections as well as in taeniasis due to either $\mathbf{T}$. saginata or $\mathbf{T}$. solium $^{5}$

Cysticercosis is caused by infections with the larval stages of the porcine tapeworm, $\mathbf{T}$. solium. It is believed that ingestion of food contaminated with ova, is the most common mechanism of infection. Once ingested, eggs hatch in the small bowell, burrow into the venules and travel to distal sites, usually subcutaneous tissue, muscles and brain (parenchyma, sub-arac noid space or ventricular system,, where they develop into mature larvae or cysticerci after few months.

The clinical manifestations of CNS cysticercosis depend on the location, pathological pro cess produced by the parasite, patient's inflam matory response to larvae, and alterations of CSF dynamics. Parenchymal lesions have the tendency to cause seizures, visual tract damage, hemiparesis and cranial nerves involvement. Diffuse parenchymal cysts often result in acute cerebral edema with intracranial hypertension, visual impairment, and mental changes. Meningeal locations produce an aseptic, chronic meningites syndrome; while cysts obstructing the fourth ventricle may cause severe headache, vertigo, vomiting and flaccid quadriplegia following sudden head movements, which is known as Burn's Syndrome ${ }^{3,7}$.

$P Z Q$, at a dose of $50 \mathrm{mg} / \mathrm{kg}$ per day for 14 days, permits the treatment of most cases with intraparenchymal cysts and to a lesser degree, 
TORRES R.. J. R.: NOYA G.. O.: NOYA. B. A. de \& MONDOLFI G.. A. - Seizures and praziquantel. A case report. Rev. Inst. Med. trop. São Paulo. 30 (6): 433436.1988

of those with chronic meningitis due to basal arachnoiditis. The drug has not proved effective in the treatment of intraventricular $\operatorname{cysts}^{8.9}$.

When given in single doses, PZQ is well tole rated, with frequent though usually mild and reversible side effects, such as abdominal pain (17 to $54 \%)$, malaise $(0.3$ to $14 \%)$, diarrhea 110 to $25 \%$ ), fever (11 to $21 \%$ ) and headache 16 to $17 \% 1^{5}$

We report herein, the case of a young man in whom the administration of $\mathrm{PZQ}$ at a low $\sin$ gle dose for the treatment of an intestinal infec tion by $H$. nana, triggered the occurrence of re peated episodes of seizures. A thorough clinical evaluation showed that he was suffering from an until that moment asymptomatic brain cysti cercosis.

\section{CASE REPORT}

A 27 year old male accountant had been in study at the Gastroenterology Service, because of left flank tenderness over a period of one year. Clinical and laboratorial evaluations revealed only a mild eosinophilia of $7 \%$ and the presence of Hymenolepis nana ova in the stools. He was given $20 \mathrm{mg} \mathrm{kg}$ of $\mathrm{PZQ}$ as a single oral dose. Six hour later, he noticed spontaneous toni-clonic movements of the right hand during 10-15 minutes, followed by tonic contracture of the right upper limb lasting 15 seconds approxima tely. Afterwards, he complained of severe diffuse headache and had a generalized seizure. The fo. llowing week, he suffered from similar convulsive episodes, on the account of which he was evalua. ted at the Neurology Service of the same hospital. A brain CAT scan revealed two cystic lesions. $12 \mathrm{~cm}$ in diameter with ring enhancement and mild surrounding edema on the left parietal cortex (Figure 1). The EEG showed a normal pattern without epileptiform activity. A spinal tap failed to reveal any CSF abnormality. A new hematology revealed an eosinophils count of $11 \%$. A complement fixation (Weimberg's) test performed on the CSF was negative.

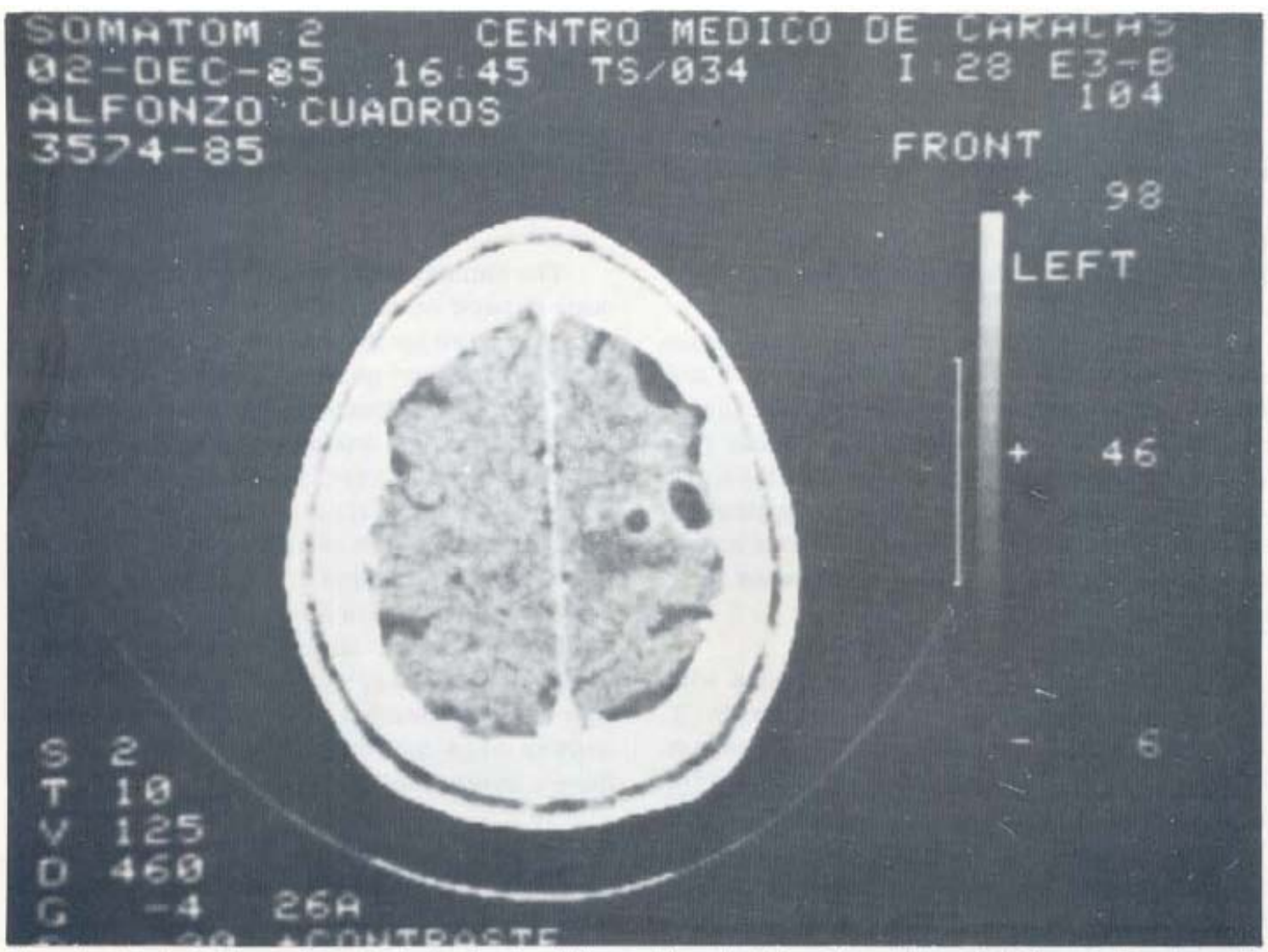

Figure 1 - Brain CAT scan the patient showing two left parietal, cortical, hypodense lesions, 1 to 2 cu: in diameter, with mild surrounding edema and ring enhancement after contrast administration. 
TORRES, R., J. R.: NOYA G.. O.: NOYA. B. A. de \& MONDOLFI, G. A. - Seizures and praziquantel. A case report. Rev. Inst. Med. trop. São Paulo, 30 (6): 433 436. 1988.

He was given a 14 days course of $50 \mathrm{mg} / \mathrm{kg}$ per day of $P Z Q$ orally, in three divided doses, plus $20 \mathrm{mg} /$ day of prednisone. He continued to take $300 \mathrm{mg}$ per day of diphenilhydantoin and $100 \mathrm{mg} /$ day of phenobarbital also.

A new spinal tap, performed after comple ting treatment with $P Z Q$, revealed a positive complement fixation test for cysticercosis in the CSF at a titer of 1:2. CAT scan films taken two months later did not show any residual lesions.

The patient was discharged on phenobarbital treatment and had remained asymptoma tic after 1 year of follow up.

Worldwide, cysticercosis is regarded as the most common parasitic infection of the CNS. It is particularly common in Mexico and other parts of Central and South America, Africa, In dia, China, Eastern Europe, and Indonesia

In general, cysticercosis affects communi ties in which hygienic conditions are poor, al though it is occasionally found in middle and upper class inhabitants of urban areas.

Neurocysticercosis may represent a mayor public health problem in some developing regions, where general autopsy series place its prevalence as high as $3.5 \%$, whereas $25 \%$ of all intra cranial masses recorded at necropsy are due to cysticercosis $^{1}$

The CNS is involved in $60-96 \%$ of those with cysticercosis. Less than $20 \%$ have solitary cysts and over 200 cysts have been found in some brains. Cerebral involvement may be asympto matic for long periods. The average interval from initial infection to onset of symptoms is approximately 5 years, with a range from a few months to 30 years $^{3,6}$. Between 53 to $59 \%$ of patients with neurocysticercosis have epilepsy and it is the sole manifestation in 18 to $34 \%$. Focal seizures have been reported in up to $75 \%$ of patients ${ }^{3}$ 6.

In epileptic patients, the CAT scan is far mo re useful than serology in stablishing the diagno sis. Lesions suggestive of cysticercosis (multiple calcifications or multiple cystic lesions), are seen in $71.4 \%$ of epileptic patients who have CAT scans. On the other hand, only $42.1 \%$ of those with meningitis show other neurological mani festation. There appears to be a trend toward decreased frequency and severity of seizures in epileptic patients, even without treatment, after six months of observation ${ }^{1,3,6}$.

PZQ is well tolerated by humans, and there seems to be no long-term toxicity. The drug is rapidly absorbed after oral administration. and it is excreted with its metabolites through the kidney. Serum concentrations of $1 \mathrm{mcg} / \mathrm{ml}$ of the drug are obtained after single oral administra tion of $50 \mathrm{mg} / \mathrm{kg}$. Half life averages 4 to 5 hours. Once in the blood, $76 \%$ of the $P Z Q$ is reversibly bound to serum proteins, disappearing rapidly from the intramuscular space as it is concentrated into various tissues. $P Z Q$ penetrates blood-brain barrier, reaching CSF concentrations, of $15-20 \%$ of those reached in serum ${ }^{2}$.

Fever, headache, nausea, vomiting, menin gismus, seizures, and increased intracranial pressure are associated with PZQ therapy, sug gesting the destruction of cysts and a resulting inflammatory response. Administration of corti costeroids lessens these symptoms but there are not clear guidelines for use of steroids in such conditions $^{4,7,8}$.

On the other hand, tolerance studies of PZQ in human volunteers did not reveal any relevant abnormality in hematological tests, urinalysis, EKG and EEG, as well as in physical or psychological examination or neurological tests. At the high dose of $75 \mathrm{mg} / \mathrm{kg} / \mathrm{day}$, some volunteers complained of mild fatigue, malaise and nausea. However, intense nausea, vomiting, severe gastritis and sinus tachicardia with a heart rate abo. ve 140 beats per minute has been reported by us in a patient receiving $40 \mathrm{mg} / \mathrm{kg} /$ day of $P Z Q$ in six divided doses ${ }^{2}{ }^{10}$.

\section{RESUMEN}

\section{Convulsiones en un individuo tratado con Pra- ziquantel}

Un paciente de sexo masculino de 27 años de edad desarrolló convulsiones luego de recibir una dosis única de $20 \mathrm{mg} / \mathrm{kg}$ de praziquantel para el tratamiento de una infección intestinal por Hymenolepis nana. Ulteriores evaluaciones clínicas y de laboratorio mostraron que el pa 
TORRES. R.. J. R.: NOYA G.. O.; NOYA. B. A. de \& MONDOLFI. G. A. - Seizures and praziquantel A case report Rev. Inst. Med. trop. Sảo Paulo, 30 (6): 433436.1988.

ciente sufria de una hasta ese momento asinto mática cisticercosis del parenquima cerebral Praziquantel debe ser utilizado con precaución en aquellas areas en las cuales la cisticercosis representa un problema importante de salud pública. La ocurrencia de convulsiones inespera das en un individuo que este siendo tratado con el compuesto, hace necesario la exclusión de cis ticercosis del SNC.

\section{REFERENCES}

1. GRISOLIA.J.S.\& WIEDERMOLT.W. C. - CNS cysticer cosis. Arch. Neurol. (Chic.), 39: 540 544, 1982

2. LEOPOLD, G; BUMRING, K. U : DIEKMAN, H. W STEINER, K. \& GRABE, A. - Clinical pharmacology in normal volunteers of praziquantel, a new drug against schistosomes and cestodes. Europ. J. clin. Pharmacol. 14: 281291.1978

3. McCORMIK, G. F.: CHI-SING, Z \& HEIDEN, J. -... Cysti cercosis cerebri Review of 127 cases. Arch. Neurol. (Chic.), $39: 534.539,1982$

4. NASH, T. E. \& NEVA. F. A. - Recent advances in the diagnosis and treatment of cerebral cysticercosis. New Engl. J. Med., 311: 1492 1496. 1984.
5. REZENDE, G. - Praziquantel experiencia clmica mun dial. Bol. chil. Parasit., 38: 52 63, 1983

6. SCHENONE. H.; VILLAROEL, F.: ROJAS, A. \& RAMI REZ, R. - Epidemiology of human cysticercosis in Latin America. In: FLISSER. A.: WILLMS, K et al., ed. Cysticercosis. Present state of knowledge and perspectives New York. Academic Press, 1982.

7. SHANLEY, J. D. \& JORDAN. C. - Clinical aspeets of CNS cysticercosis. Arch. Intern. Med, 140: 1309 1313.1980.

8. SOTELO. J.: ESCOBEDO. F.: RODRIGUEZ. J.: TOR RES. B \& RUBIO. F - Therapy of parenchymal brain cysticercosis with praziquantel New Engl. J. Med., 16: 1001 1007. 1984

9. SOTELO, J : TORRES, B.: RUBIO. F : ESCOBEDO, F \& RODRIGUEZ, J. - Praziquantel in the treatment of neurocysticercosis: long term follow up. Neurology. 35: 752755,1985

10. TORRES, J. R.: NOYA, O.; NOYA, B. A.: MOULINIEKE, R. \& MARTINEZ, E - - Treatment of proliferative sparga nosis with mebendazole and praziquantel Trans. roy. Soc. trop. Med. Hyg., 75: 846847,1981

Recebido para publicaçào em 2051988 